\title{
Tele-Psychotherapy in Germany (Comment)
}

Dr. Carolina Diamandis ${ }^{1}$ and Nicole Feldmann ${ }^{1}$

${ }^{1}$ Affiliation not available

May 20, 2021

\begin{abstract}
Long strictly forbidden, tele-psychotherapy has now also found its way to Germany. This article is one of the first experience reports, written a year after the liberalization of this kind of medical service in all 16 German federal countries. The Feldmann Paper explains the current situation in Germany (May 2021).
\end{abstract}

\section{Hosted file}

The Feldmann Paper.pdf available at https://authorea.com/users/410930/articles/522726-telepsychotherapy-in-germany-comment 